\title{
Framing Privatisation: The Dominance of Neoliberal Dis- course and the Death of the Public Good
}

\author{
Ciara Graham* and Henry Silke** \\ *School of Business \& Humanities, Institute of Technology Tallaght, Dublin 22, Ire- \\ land, ciara.graham@it-tallaght.ie
}

${ }^{* *}$ School of Culture and Communication, University of Limerick, Limerick, Ireland, henry.silke@ul.ie

\begin{abstract}
This paper looks at the privatisation of Bórd Gáis Éireann (BGÉ) in 2014 and the treatment of this issue by the mainstream print media in Ireland. From a contextual perspective, this privatisation came in the wake of the global economic recession and its longer-term implications for Ireland. The media's coverage of the sale was not found to be impartial: both the volume and thrust of the articles were inclined to portray privatisation in a favourable, noncritical light. The majority of content was presented within Neoliberal frames, with a competitive frame being dominant; in other words, the topic was treated from a market or business perspective rather than the perspective of the public good or wider society. A consistent source bias was also found favouring business or market interests with almost no representation of workers or civil society. Theoretically the paper argues that the framing of privatisation as a business and consumer issue, rather than a political one or that of the public good, acts to detract from the political aspects of the appropriation of public assets by international capital, including the implications for infrastructure, economic development and accountability to democratic structures, none of which receive sufficient journalistic attention.
\end{abstract}

Keywords: Ireland, Privatisation, Journalism, Business Journalism, Economic Journalism, Ideology, Framing, Sourcing analysis, Bórd Gáis Éireann

\section{Introduction}

This paper looks at the privatisation of Irish state assets and the treatment of this issue by the mainstream print media in Ireland. Specifically, it looks at the case of Bórd Gáis Éireann (BGÉ), the publicly-owned Irish gas and related services provider, and its sale by the Irish government between March and June 2014. From a contextual perspective, this sale came in the wake of the global economic recession and its longer-term implications for Ireland. The treatment of that privatisation by Irish newspaper publications published between February 2014 and July 2014, and categorised using the newspaper data archive Lexis Nexis, has been examined using Critical Discourse Analysis. Wodak (2007) defines this methodology as one which analyses the transparent structural relationship of dominance, discrimination, power and control that is manifest in language.

Newspaper coverage of the sale could not be found to be impartial: both the volume and the thrust of the articles were inclined to portray privatisation in a favourable, noncritical light. Most of the content presented conformed with Neoliberal frames, with a competitive frame being dominant; essentially, the topic was treated from a market or business perspective rather than the perspective of the public good or wider society; the latter might have been expected since the divestment of a public asset was in 
question. A consistent source bias was also found favouring business or market interests with almost no representation of workers or civil society.

The issue of the public good was under-reported. Indeed, it was noted by Money Guide Ireland in June 2014 that the Irish population was "probably not aware" that the privatisation had taken place and that even "[BGÉ's] own customers would not have noticed"; because, while the sale was approved by the European Union on 16 June, the takeover had "already quietly happened" (Money Guide Ireland 2014).

This paper argues that, theoretically, the framing of privatisation as a business and consumer issue, rather than a political one or that of the public good, acts to detract from the political aspects of the appropriation of public assets by international capital, including the implications for infrastructure, economic development and accountability to democratic structures, none of which receive sufficient journalistic attention. Moreover, the lack of analysis does a disservice to the decades of investment by the Irish state and citizenry into developing key infrastructure and heavy industry.

An important topic of discussion is that of self-reflection within journalism and the media sphere. Following the 2008 crash and post-privatisation failures such as Eircom, one might conceivably expect a more critical media, willing to question neoliberal assumptions such as 'self-regulating' markets and the superiority of privately controlled enterprises and markets; moreover, a more pluralistic approach to economic reporting including heterodox economic voices is the least a long-suffering public should expect from economic journalism.

\subsection{Bórd Gáis Éireann - A Brief History}

BGÉ was established as a statutory corporation under the Gas Act 1976 and it operated under the Gas Acts 1976 to 2009 (McCarthy 2011). Since its incorporation, it served as the state provider of gas and related services until the government's decision to divest the asset. Prior to this sale in 2014, BGÉ was majority-owned by the state through the Minister for Finance (86.73\%) and the Minister for Communications, Energy and Natural Resources (10\%), with the balance $(3.27 \%)$ held by an Employee Share Ownership Trust (Ibid.). The BGÉ Group was comprised of two main businesses: Bórd Gáis Networks and Bórd Gáis Energy; and an autonomous subsidiary, Gaslink Independent System Operator Limited, which is responsible for the operation, maintenance and development of the gas transmission and distribution networks in Ireland.

The Review Group on State Assets and Liabilities, reporting in April 2011 and chaired by Colm McCarthy (2011), recommended "that the remaining operations of BGÉ, other than gas transmission and interconnection, should be privatised as a single entity" (Ibid.). In February 2012, the government announced its intention to sell Bórd Gáis Energy, the company's retail, trading and assets divisions (Ervia 2015). Bórd Gáis's purchase deal for $€ 1$.1bn by Centrica was approved by European Commission in June 2014 (Newstalk 2014). Three companies purchased these assets: UK-based Centrica acquired the main Energy sales business, supplying approximately 900,000 households and businesses, as well as taking over the Whitegate gas-powered electricity station in Cork (O'Donovan 2014); Canadian group Brookfield Renewables acquired Bórd Gáis's existing and planned wind farm developments; and the UK-based Icon Infrastructure purchased Firmus Energy, a Bórd Gáis holding which supplied and distributed gas within Northern Ireland (Ibid.). 


\section{Political Economy of Privatisation}

\subsection{Irish Economic Situation and Privatisation}

The economic and financial woes of the Irish state over the last seven years are welldocumented, and indeed it has been a key element of the European Troika's proposed "recovery" plan that key state assets be privatised (Palcic and Reeves 2013). The European Union (EU) has been fixing a firm agenda for the public-private debate across the EU states (Sweeney 2004). The EU has focused firmly on competition and as such prevents the use of state aids for faltering companies, both public and private. Moreover, debt-compromised nations are faced with the stark choice from the World Bank and International Monetary Fund (IMF) that before any new development loans will be authorised, "structural adjustment" via privatisation and shrinking the role of the state is required (Ellwood 2003). These urgencies, of themselves, do not make a strong case for privatisation from a business perspective - not least the fact that Bórd Gáis seems to have been undervalued by approximately $€ 300$ million at time of sale (Hearne 2015; Reynolds 2014).

\subsection{Neoliberalism and Privatisation}

In his study of the high-profile privatisation of state-owned Telecom Éireann, Sean Phelan (2003) defines neoliberalism as the structural and ideological changes which have taken place in political economy since the 1970s and 1980s. Plehwe (2009) asserts that the impact of the neoliberal thought collective was not widely observed until the late 1970s, and not before the 1980s did it reach the status of "authoritative development knowledge"; which economic historians such as John Toye (1993) refer to as the neoliberal 'counter-revolution'. Van Horn and Mirowski (2009) recognise the role that the rise of the Chicago School of Economics played in the overall progression of the neoliberal approach from its post-war inception until its wider acceptance during the late 1970s. The advocacy of the powerful administrations of British Prime Minister Margaret Thatcher (1979-1991) and US President Ronald Reagan (1980-1988) cannot be understated, and they underscore the political links that have contributed to its continuing prominence.

These ideas centred upon a resurgence of 19th-century ideas associated with laissez-faire economic liberalism, advocated by the eminent intellectuals Friedrich von Hayek, Karl Popper and Milton Friedman, among others, who supported extensive economic liberalisation and its key principles: market orthodoxy, privatisation, deregulation, free trade, fiscal austerity and reductions in government spending in order to restrict government involvement with and simultaneously boost the private sector's role within the economy (Duménil and Lévy 2004; Palley 2004; Boas and Gans-Morse 2009; Haymes et al. 2015). As stated, privatisation of state assets is a key tenet of the neoliberal approach to economics, attributed to the early workings of the Mont Pelerin Society (Williamson 2004). Allen (2009) notes that orthodoxy calls for the shrinking of the state and endorses the idea that public enterprises are inefficient and in need of privatisation.

A number of other key factors have contributed to the global rise of privatisation policy in the latter part of the 20th century. The breakdown of the Bretton-Woods Agreement (discussed in detail in Duménil and Lévy 2004) dealt a hammer-blow to post-war Keynesianism; this was followed by the substantial expansion of the Kennedys (1962-67) and subsequent rounds of the General Agreement on Tariffs and Trade (GATT; concluding in the incorporation of the World Trade Organisation (WTO) in 1993) (WTO 1994). These developments coincided with the ideological enchantment 
of both the Reagan and Thatcher administrations with Friedmanesque market fundamentalism; which culminated in many high-profile disposals of lucrative state assets.

Williamson (2004) includes the "Privatisation of State-owned Enterprises" on his elusive list of 'desirable' economic policy tenets, the Washington Consensus, prescribed for Latin American economies during the late 1980s. Williamson (2004) recognises that privatisation was the single doctrine of the ubiquitous Consensus plan, which can trace its neoliberal origins to those advocated by the Mont Pelerin Society, and he attributes the policy of privatisation to Margaret Thatcher as her "principal personal contribution to economic policy worldwide"1.

\subsection{Privatisation as Primitive Accumulation}

Harvey (2004) discusses the global tendency towards the commodification of public assets and the privatisation of public utilities as one response to the crisis of capital accumulation. He posits that this is a form of primitive accumulation (Marx 1967/1867), which includes privatisation and commodification; the conversion of various forms of property rights, such as collective or state rights, into exclusively private property rights; the commodification of labour power and the suppression of indigenous or alternative forms of production. For Harvey, the corporatisation and privatisation of previously public assets and public utilities constitute a new wave of the "enclosure of the commons" (2004).

Mercille and Murphy (2015) draw upon Harvey's theory to discuss privatisation policy in Europe in the wake of "the great recession". The authors discuss an ongoing intensification of privatisation activity, both in Europe and globally, in the wake of the 2008 crisis. They posit the various types of privatisation in the post-crisis European case, including:

1. Private Repossession (of nationalised banks);

2. Restructuring (that is the conventional privatisation of State-Owned Enterprises (SEOs) operated on a commercial basis before and after privatisation)

3. Commodification - defined as the privatisation of public assets outside the capitalist system and converted into commodities;

4. Privatised stimulus - this is represented by private public partnerships (PPP).

Their work highlights the necessity of studying the media treatment of post-2008 privatisation, and demonstrates the relevance of this study.

\subsection{The Ideology of Privatisation}

Colin Meek (1996) draws attention to the way in which the privatisation process undertaken by the Thatcher administration in respect of the Initial Public Offering (IPO) of shares in British Telecom in 1984 (and subsequent sales of British Gas in 1986 and Water Services in 1989) "was woven into the fabric of a wider policy programme which included dramatically increasing the number of individuals who owned shares". This, of course, emphasises the ideological role that the privatisation of state assets can play when individual citizens are encouraged to assume a personal financial ownership stake in a business operation which had previously existed to serve their and their fellow citizens' needs. Meek goes further in stating that each new privatisation was

\footnotetext{
${ }^{1}$ Although not part of the Conservative Party manifesto prior to the 1979 election (Palcic and Reeves 2011), the policy of privatisation was initiated with the Initial Public Offering (IPO) of British Telecom in 1984 and followed with a litany of high profile disposals of important state assets in the subsequent years, including British Gas in 1986, British Water in 1989 and British Rail from 1993.
} 
used as a weapon in the British Conservative government's own fight against its political opponents, the Labour Party, whose key policy plank of maintaining a strong trade union presence within nationalised industries was fundamentally undermined (Ibid.). Meek notes that while the pursuit of competition and efficiency may have been a plausible objective used by the Conservative administration in the pitch for privatisation, the reality was that, once sold, new shareholders were quite content to maintain the healthier returns from a monopolistic player (lbid.).

However, there are many challenges to the liberal economic orthodoxy of privatisation. In an examination of the theory and evidence of examples of privatisation around the globe covering a period of the previous three decades, Ram Mohan (2002) broadly challenges the presumption that privatisation is the key to improved performance on the basis that neither economic theory nor empirical evidence itself necessarily points to any indubitably positive conclusions about privatising publicly-owned companies. Palcic and Reeves (2011) concur: they conclude that the net benefits of privatisation, both theoretical and empirical, are unclear. In particular, they note the wider economic and distributional impacts and the effects on stakeholders are especially problematic, due in part to the fact that, for methodological reasons, many empirical studies focus on micro-factors, such as enterprise performance, at the expense of measuring overall welfare effects (Bel et al. 2010; Lundahl et al. 2007). Moreover, while privatisation's 'benefits' are questionable, many theorists (Bond 2003; Diokno-Pascual 2003; Ellwood 2003; George 2003; Hall 2003; New Internationalist 2003; Pollock 2003) maintain that the policy can often bring with it many disadvantages; namely price inflation, excessive executive compensation, tax avoidance and evasion, under-valuation of an entity's network, raised costs in search of profits, publicly leveraged buy-outs of private firms, workforce pay reduction and redundancy, subsidised operation of privatised enterprise, inability of low income earners to purchase basic services due to price increases, exploitation of market power, loss of public accountability, protectionism, corruption, and bribery. In worse cases the scenario can be even more pronounced: activities such as asset stripping, as in the case of Irish Telecommunications provider, Eircom (Sweeney 2004), and insider loans and trading have been seen (Akram 2003; New Internationalist 2003; Letza et al. 2004). A strong body of research suggests a deviation from the dominant orthodoxy of privatisation as a function of market adhesion, which Clarke (1994) describes as having "swept through the world" since the early 1980s, especially in the advanced OECD countries. This also alludes to a deviation from the normally positive treatment of privatisation in the mainstream media, which Herman (1982) argues serves the economic interests of dominant media, who are often owned by the same businesspeople who are benefitting from the privatisations they describe.

Following in the footsteps of its UK counterparts, the Irish government has sought to privatise a number of key state assets, the most high-profile of which, both in terms of its launch and subsequent demise, was Eircom in 1999. The fanfare which accompanied its launch to market by the mainstream Irish media is renowned, and imbued with 'neoliberal assumptions', as Phelan (2003) notes in his thesis on that privatisation. From the first disposal of Irish Sugar in 1991, the state has gone on to privatise SOEs from industries as diverse as banking and aviation (Sweeney 2004). While the state had disposed of its interests in several industries, post-economic crash, the issue took on a new significance. Palcic and Reeves (2013) observe that privatisation in Ireland has been immensely controversial. They note that the privatisation of the former stateowned telecommunications provider, Eircom (then known as Telecom Éireann), continues to hamper Irish economic development, as it had "disastrous consequences" for 
the development of a modern information technology infrastructure. They also note that the theoretical case for privatising state assets is "not strong" and that the empirical evidence is mixed. In recent years, state ownership has taken on negative associations following the banking collapse and the 'inadvertent' nationalisation of six malfunctioning banks under the Banking Guarantee.

\section{Journalism and Privatisation}

\subsection{Business Journalism and the Representation of Economic Issues}

Business journalism has come under particular scrutiny following the 2008 economic crisis, primarily in relation to the question of why business journalism missed, downplayed or denied the crisis. On a more theoretical level, the working practices of business journalism, not least journalists' relationship to the industries and sources they report upon, has been questioned. In a publication edited by Schiffrin (2011) on the failure of the American Press to warn of the crisis, a number of factors were discussed, including time pressures that led to incomplete reporting; a lack of technical knowledge; and a general unwillingness to question those with economic power. In an earlier work, Davis (2002) discussed how businesses increasingly employ public relations agencies to ensure positive coverage and shape the business agenda. As discussed by Fraser (2009), business journalism also betrays short memories that do not seem to recall even recent economic crises, never mind including a historical perspective.

In terms of professional ideologies, it has been found that business journalists do not define journalism in the same ways as traditional 'fourth estate' ideologies, especially in terms of the role of watchdogs for the public good (Usher 2013; Tambini 2010). Moreover, ideologies of impartiality may not even be on the business journalist's radar at all, since key neoliberal frames are assumed as the sole reality rather than being simply one economic theory of many. In some cases, the very role of journalism itself seems to be recast in market terminology (Freedman 2008). For example, on the appointment of Stephen Rae as a new group editor of International News and Media (INM) in 2013, INM chief executive Vincent Crowley stated:

"A key challenge for Stephen and our exceptional team of editors and journalists is to make our market leading content and great writers more accessible to consumers in a manner and at a price that sustains consumer engagement and the integrity and quality of our reportage" (Irish Independent 2013).

There are also wider ideological practices at work across the media sphere. Preston and Silke (2011) identify the concept of market-orientated framing; this framing privileges market viewpoints of societal issues over other possible viewpoints, and acts to mystify or disguise what are actually political and social decisions by posing them as mere "technical issues". In the quotation above, for example, the superiority of market systems over others is assumed and the discussion therefore revolves not on the key forms of policy decisions, but rather on the best way to implement 'market-friendly' policies. 


\subsection{Business/Economic Journalism and Sourcing}

Many studies of news production and news content construction in the media system point to the growing capacity of certain privileged actors to shape and frame what passes for mediated news and information supposedly orientated to the public, and towards informing decision-making (Preston 2009). These studies point to growing imbalance over time between interest-laden or promotional news-making resources on the one hand, and the resources essential for investigative, 'watchdog' and other forms of journalism orientated to the public on the other. In a study of the London Stock Exchange, Davis $(2007,19)$ conducted 95 semi-structured interviews at 80 city locations over two periods. Davis found that financial journalists, due to greater competition, are forced to produce more copy with fewer resources; this has, in turn, led to a dependency on 'information subsidies' from quoted companies, financial public relations firms and brokers' analysts and investor relations companies (Ibid., 23). Some recent research also points to a 'risk aversion' among journalists against making negative predictions, showing conformity of economic journalists and the 'capture' of journalists by their sources, which act to reinforce both reporters' and investors' opinions (Thompson 2003, 30).

\subsection{Journalism and the Representation of Privatisation}

Phelan (2007), in his research into the editorial treatment of the privatisation of Telecom Éireann, found an underlying assumption in all six newspapers sampled; they favoured liberalised and privatised telecoms markets over state involvement. Phelan found and discussed three key neoliberal assumptions: firstly that the full privatisation of the company is desirable; secondly that the notion of direct state involvement in a modern telecoms market is archaic; and finally that public participation in the stock market should be encouraged (Ibid., 9). This is framed as an act of modernisation (lbid., 16) rather than appropriation. Differences only came about on appropriating blame after the decline in the share price. Interestingly, only one newspaper, the Sunday Tribune (now defunct), did not advocate the immediate full privatisation of the company, but this was from a strategic rather than an ideological perspective, which proposed that holding back on some of the sale might gain a higher price later (Phelan 2007, 14). Greater ideological differences appeared between the titles when the existing management was attacked by a more populist INM group of newspapers, but defended by the Sunday Business Post and the Irish Times. Of course this populist faux equalitarian attack on the existing management by the INM titles must be taken in the context of wider Political Economy. A consortium led by Tony O'Reilly, the then controlling shareholder in the INM group, would go on to become the controlling shareholder in Eircom in 2001 (Phelan 2007, 24).

A study by Doğu (2015) comparing alternative with mainstream treatment of worker protests against the privatisation of the Tobacco, Tobacco Products, Salt and Alcohol Enterprises (TEKEL) in Turkey found that while, not unexpectedly, alternative media tended to show support for workers, the framing of this support relied on mainstream framing practices. The study found that the mainstream media paid much less attention to the protests compared to the alternative media (Ibid., 638). However, the study found that both mainstream and alternative media focused more on the specific acts of the protests, exemplifying 'results-orientated journalism'; and paid less attention to the foundation of the resistance. Here, broader issues such as privatisation, market economy, unemployment and class consciousness were less referred to (lbid., 648).

A major study on the treatment of privatisation in the English-language South African press was carried out by Mayher and McDonald (2007). The authors looked at the 
English-language print media over a four-and-a-half-year period from May 2000 to October 2004, which the authors describe as a particularly intense period of debate over privatisation. The study focused on the four key municipal services of water, electricity, sanitation and waste management. In total, $41 \%$ of the sample (of 647 articles in 34 English-language newspapers and wire services) were classified as pro-privatisation, $38 \%$ as anti-privatisation, and $21 \%$ as neutral (Mayher and McDonald 2007, 449). However, when the researchers coded their sample for level of analysis they found $69 \%$ to be what they term 'unanalytical'; only $21 \%$ were considered analytical (Ibid.) $)^{2}$. This may be in part to the 'dumbing down' of South African journalism as discussed in the literature (de Beer and Steyn 2002). The authors suggest it may also present a reflection of what they describe as an ingrained ideological bias amongst journalists and editors towards the marketisation of municipal services, alongside a willingness to allow unproblematised assumptions and positions on the topic to be published (Mayher and McDonald 2007, 449).

The authors identified 17 frames in total, nine of which they describe as pro-privatisation and eight as anti-privatisation (Ibid., 450). Of the pro-privatisation frames the most frequent was "there is no alternative to the markets" ('TINA'). Another key frame was that "privatisation is pro-poor" because it leads to better service delivery, a direct counter to the anti-privatisation frame that privatisation is pro-capital. Anti-privatisation activists were also sometimes framed as "anti-patriotic", "ultra-left" and sometimes "criminal", usually by quotes from government members. The major anti-privatisation frames were ones of corruption, human rights and worsening services for the poor (lbid., 452-454). In their analysis of discourse trends in a sub-sample of the articles, the authors found use of positive euphemisms for privatisation, such as 'partnership', 'restructuring' and 'efficiency'. The authors conclude that while there appears to be, on the surface, relatively balanced coverage, due to "the quality of this news coverage, the source of the news items, the kinds of information packages used to explain the debate, and the actual phrases and terminologies employed" (Ibid.) pro-privatisation is solidified as the dominant discourse.

Also in South Africa, Kariithi and Kareithi (2007) looked at the coverage of a national anti-privatisation strike in 2002. The authors found that media coverage of the October 2002 Congress of South African Trade Unions (COSATU) national strike against privatisation legitimated what they define as three tenets of neoliberalism - "globalisation, efficiency and flexibility" - while delegitimating organised labour's socialist ideology. The study looks at all major English-language newspapers, two of which (The Star and the Sunday Independent) belong to the International News and Media Group (INM). The authors found that media texts claimed that the COSATU strike would damage South Africa's image in an age of globalisation and spook international investors (Kariithi and Kareithi 2007, 469) and that COSATU do not understand the "realities of Globalisation" (Ibid.).

${ }^{2}$ Articles were then evaluated according to their degree of analysis (with -5 representing 'very unanalytical' and +5 representing 'very analytical', with gradations in between). An unanalytical article is one that would, for example, make a statement on the merits (or demerits) of privatisation without explaining what the author meant by 'privatisation' or how these arguments can play themselves out in practice. An analytical article, by contrast, would "describe the particular form(s) of privatisation being discussed, the pros and cons of different forms of privatisation (or the similarities between them), and perhaps offer evidence to illustrate these points" (Mayher and McDonald 2007, 449). 


\section{The Irish Press and the Privatisation of BGE}

\subsection{Research Methodology}

In order to set the parameter of the search as widely as possible, the search term "Bórd Gáis" was entered into the Lexis Nexis newspaper database (excluding the words 'theatre' and 'sport') $)^{3}$. A total of 237 articles were returned from a search of all Irish daily and weekend editions of print and online news publications from 1 March to 30 June inclusive (incorporating the Belfast-based 'Irish News' and the 'Sligo Champion'. This covered the four-month period during which the sale of BGÉ was processed and approved by the European Union. Seventy articles were discounted as they made no reference to the sale of BGÉ, leaving a total of 167 relevant articles on the topic. All publications returned from the search were as follows (see Figure 1). Articles were returned from all of the sections featured in the publications. The majority of articles retrieved were published in the publications' News or Business sections.

\begin{tabular}{|l|l|}
\hline Irish Daily Newspapers & Irish Daily Mail \\
\hline & Irish Examiner \\
\hline & Irish Independent \\
\hline & Irish Times \\
\hline Regional Newspapers & Irish News \\
\hline $\begin{array}{l}\text { Web-based News Publica- } \\
\text { tions }\end{array}$ & RTE News Morning Round-up \\
\hline & Business World Digest \\
\hline Irish Weekend Newspapers & Breakingnews.ie \\
\hline & Sunday Business Post \\
\hline
\end{tabular}

Figure 1: Newspapers and online publications in study

\subsection{Critical Discourse Analysis and Framing}

The methodology used to analyse this data is drawn from Critical Discourse Analysis (CDA): a methodology that has developed from critical (Fowler 1991) and functional (Halliday 1985) linguistic efforts to comprehend communicative practices in society. Wodak (2007) defines this methodology as the analysis of the transparent structural relationship of dominance, discrimination, power and control that is manifest in language. Elfriede Fürsich $(2009,239)$ argues that "only independent textual analysis can elucidate the narrative structure, symbolic arrangements and ideological potential of media content". Critical Discourse Analysis will thus incorporate a framing analysis to identify the key media frames used in relation to the presentation of the privatisation.

${ }^{3}$ The words 'theatre' and 'sport' were omitted as the company is a sponsor in sporting competition and a prominent theatre in Dublin is named after the company. 
Framing describes how a news item is characterised and presented in news reports (Scheufele and Tewksbury 2007).

As stated, Framing Analysis looks at the ways in which news items are depicted and portrayed by news reports (lbid.). Frames were identified following a systematic categorisation and codification process in accordance with the methodological principles of Grounded Theory put forward by Glaser and Strauss (1967). While many other theoretical approaches concern themselves with the verification of theory, Glaser and Strauss emphasise the uncovering of concepts and hypotheses relevant to the study in question: this is an inductive rather than deductive approach to research (Ibid.) and highly applicable for news framing analysis.

\subsection{Sourcing Analysis}

A key concern among journalistic scholars from both the constructivist and institutional disciplines is that of journalistic sourcing, as its implications for the maintenance of ideology is significant. Tuchman (1978) recognises the tendency of journalism to construct rather than reflect 'reality', and that this constructed 'reality' is likely to be the one most accessible to them. Institutional media structures, which Preston (2009) terms the "meso level", examine organisational structures and factors such as time, cost and space, which indicate that journalists often rely heavily on 'newsbeats' - parliamentary, police and court sources - reflecting this institutional bias in their output. Hall et al., in their seminal work (1978), introduced the concept of 'primary definers': institutional journalistic sources who tend to be consulted first on new topics and, as such, are allowed to form an agenda and/or frame the issue, by "commanding the field" and the treatment of subsequent debate. Becker identified a hierarchy of credibility, placing those at the top of business and state organisations in a position of privilege to define "how things really are" $(1967,241)$.

\subsection{Research Questions}

A number of interrelating research questions present themselves, which the following section of the paper will endeavour to answer: How did the media cover the sale of Bórd Gáis Éireann? Was the sale adequately covered by the media? Were the issues pertaining to the privatisation of Bórd Gáis Éireann sufficiently teased out? Which frames were used? How was the issue of privatisation presented? How does the discursive structure used in reporting on Irish privatisation evidence the power or class structure inherent in such reporting? Is there evidence to suggest that economic reporting has become more critical since the 2008 crash? A key area of interest in this study is that of the area of self-reflection within journalism and the media sphere. After 2008 and privatisation failures such as Eircom, one might conceivably expect a more critical media, more willing to question neoliberal norms such as 'self-regulating' markets and the assumption that privately-run enterprise is superior to publicly-run enterprise.

\subsection{Initial Findings}

Primary analysis shows that of all those articles concerning the sale of Bórd Gáis Energy during the period surrounding its sale, a relatively small minority presented any critique of privatisation, either generally or specifically in the case of Bórd Gáis. A total of only seven articles were in any way critical of the process of privatisation. One of the key questions posed by the research was whether the articles could be classified as taking a stance on the issue of the privatisation of BGÉ. To this end, three principal categories were defined: Pro-Privatisation; Anti-Privatisation and Not-Overtly-Aligned. 
Of the 111 relevant articles analysed, 56 were found to adopt a Not-Overtly-Aligned approach to the subject, 47 took a Pro-Privatisation stance and 7 took an Anti-Privatisation position. It is therefore clear that pro-privatisation frames received much more attention than anti-privatisation. The following figure illustrates the complete breakdown of all the articles reviewed (see Figures 2, 3 and 4).

Not-

Overtly-

Aligned Privatisation Privatisation

TOTAL

\begin{tabular}{|l|c|c|c|c|}
\hline Irish Daily Mail & 9 & 5 & 0 & 14 \\
\hline Irish Examiner & 4 & 9 & 3 & 16 \\
\hline Irish Independent & 17 & 11 & 0 & 28 \\
\hline Irish Times & 0 & 0 & 0 & 0 \\
\hline Metro Herald & 0 & 1 & 0 & 1 \\
\hline Irish News & 0 & 2 & 0 & 2 \\
\hline Sligo Champion & 0 & 1 & 0 & 1 \\
\hline $\begin{array}{l}\text { RTE News Morning } \\
\text { Round-up }\end{array}$ & 6 & 1 & 0 & 7 \\
\hline Business World Digest & 4 & 5 & 0 & 9 \\
\hline Breakingnews.ie & 5 & 1 & 0 & 6 \\
\hline Sunday Business Post & 0 & 5 & 0 & 5 \\
\hline Sunday Independent & 11 & 6 & 4 & 21 \\
\hline & $\mathbf{5 6}$ & $\mathbf{4 7}$ & $\mathbf{7}$ & $\mathbf{7 1 0}$ \\
\hline
\end{tabular}

Figure 2: Initial findings by number of articles and publication 


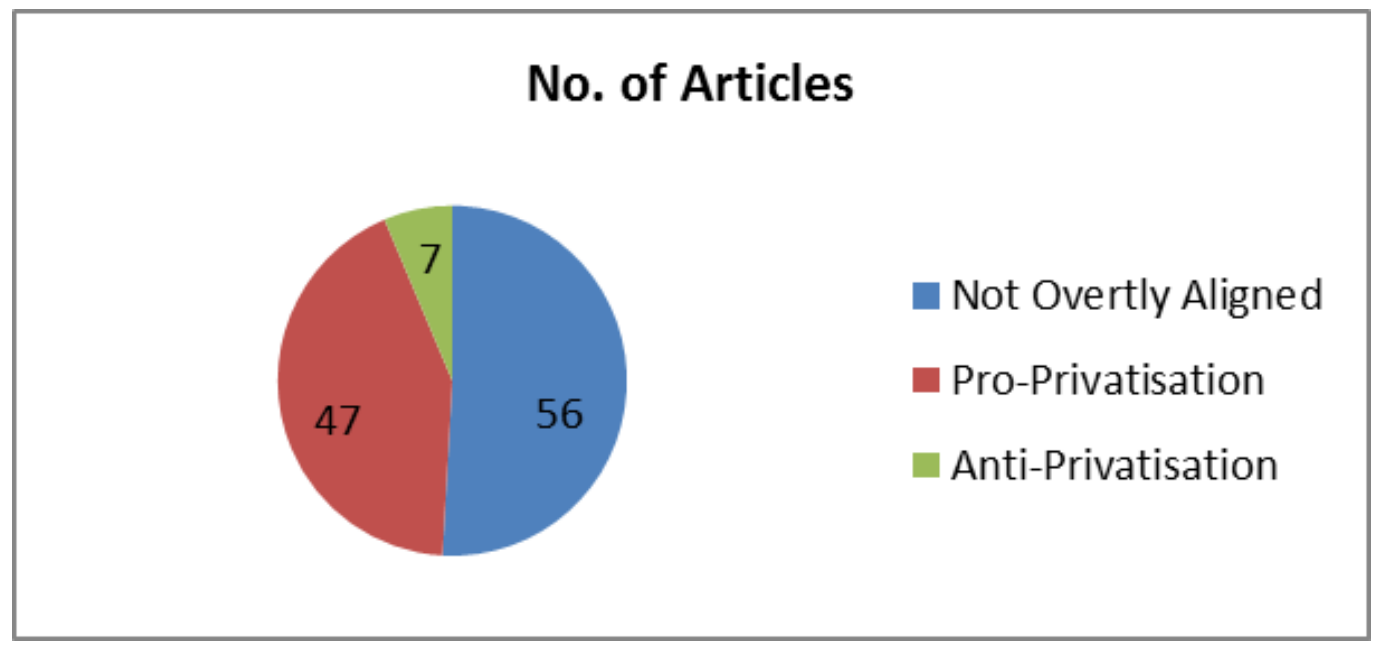

Figure 3: Initial findings by total number of articles

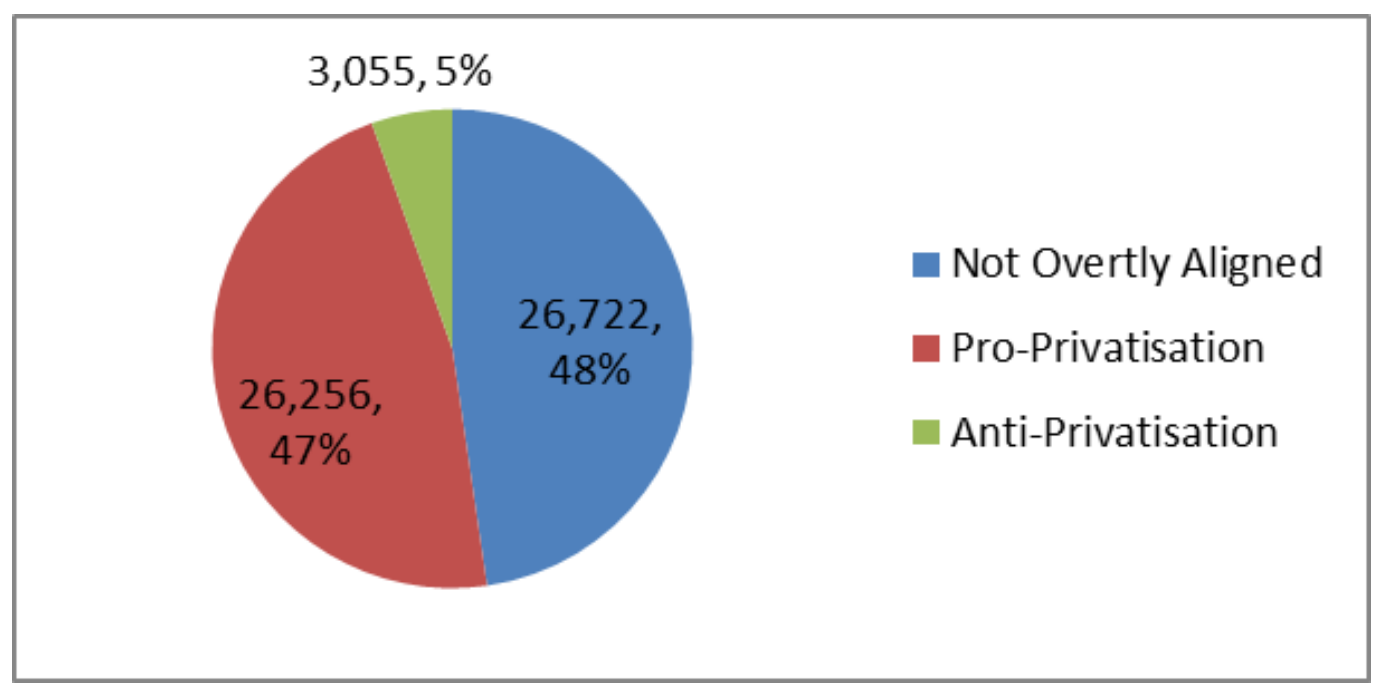

Figure 4. Initial findings by word count and percentage

\subsection{General Themes Emerging from the Discourse}

The general substance of the coverage by the media of the privatisation of BGÉ was supportive. Much of the coverage centred on the presentation of the persistent idea that the sale would be good as it would, following deregulation of the gas market, bring competition for customers, with the implication that this would cost them less in energy bills. To this end, numerous articles were constructed around the message that 'switching suppliers is good for customers' and provided numerous sources from vested interests which were used to drive home this point of view.

Where there existed any critique of privatisation, there was a degree of balance in the journalistic articles, something that was not found in those that could be classified as 'Pro-Privatisation' - essentially, in these 'Anti-Privatisation' articles, the journalist attempted to look at the bigger picture and provide some sense of equilibrium in the writing. There was no corresponding attempt to bring any such balance into the articles classified as 'Pro-Privatisation'. This reflects the findings of Kariithi and Kareithi (2007) discussed above.

Another key constituent of the coverage focused upon the impression that the divesting of its share-holding in the company by the Bórd Gáis Employee Share Option 
Scheme (ESOP) would result in a sizeable 'tax-free windfall' for employees at the expense of customers. This theme was substantiated by the use of pejorative and disparaging language, such as 'bonanza payout', 'pocketing a tax-free bonus', 'share millions' and 'trousering up to 60-odd grand'. It is interesting to note the media's portrayal of the ESOP members in this instance as workers whose entitlement to dividends is tenuous, rather than shareholders whose entitlement is assured.

Most of the articles classified as 'Anti-Privatisation' were actually only critical of the particular case and manner in which the Bórd Gáis privatisation was being handled and not of privatisation generally; these articles tended to espouse the view that the timing of the sale was wrong, rather than the sale itself, and/or that the asset(s) had been undervalued. Specifically, the inclusion of the BGÉ-owned Whitegate Power Station was viewed by a number of sources as 'undervalued' and the former Minster for Communications, Energy and Natural Resources, Eamonn Ryan, was quoted as saying that "[...] it (Whitegate) was sold at the bottom of the market for a gas power station".

\subsection{Source Analysis}

Not all articles reviewed featured sources directly, but most did (83\%). The following table (Figure 6) illustrates each of the source categories found in all the articles: the pie chart (Figure 5) represents the percentage value that these source categories comprise in the analysis. The vast majority of sources cited in articles were drawn from business and market representatives: over $44 \%$ of the total articles and $61 \%$ of those categorised Pro-Privatisation derived from these sources. Taken collectively, Government and State sources account for $42 \%$ of all the sources cited, and show the strong position that government enjoys when relating to the media. This is also, perhaps, indicative of the relationships that journalists and reporters tend to maintain within official sources, as discussed. Opposition sources accounted for $13 \%$ of the total sources, but it is interesting to note that this opposition was not ideological in nature; essentially, no Opposition parties or Deputies who might seriously challenge the policy were consulted. Given the media's strong reliance upon business- and market-based sources, we might at least expect a robust critique of the same; this was not evident. In fact, one key theme in relation to the "customer benefits of competition" was featured 32 separate times. Press Releases from Consumer Price Comparison Network, known as 'One Big Switch' (a price comparison agency) Campaign set the agenda for media coverage of the topic.

There were relatively few articles from the civil society/public category, which is interesting, given the persistently controversial nature of the topic of privatisation among the public over the decades since its widespread introduction. Most of those articles that were categorised thus were from the National Consumer Agency, thus demonstrating the characterisation of people as 'consumers', consistent with neoliberal framing analysis. The voice of workers and their representatives were all but non-existent from the media coverage of the sale. Only three articles consulted these people, either individually, or more tellingly, collectively: there was not one single source from within the Trade Union sector; in itself conspicuous by its absence. Moreover, it is especially remarkable since Palcic and Reeves (2013) note that the Trade Union bodies were the only group to provide any substantial vision for the development of the SOE sector, in the face of the Review group for State Assets and the advent of the Fine Gael New Era plan. 


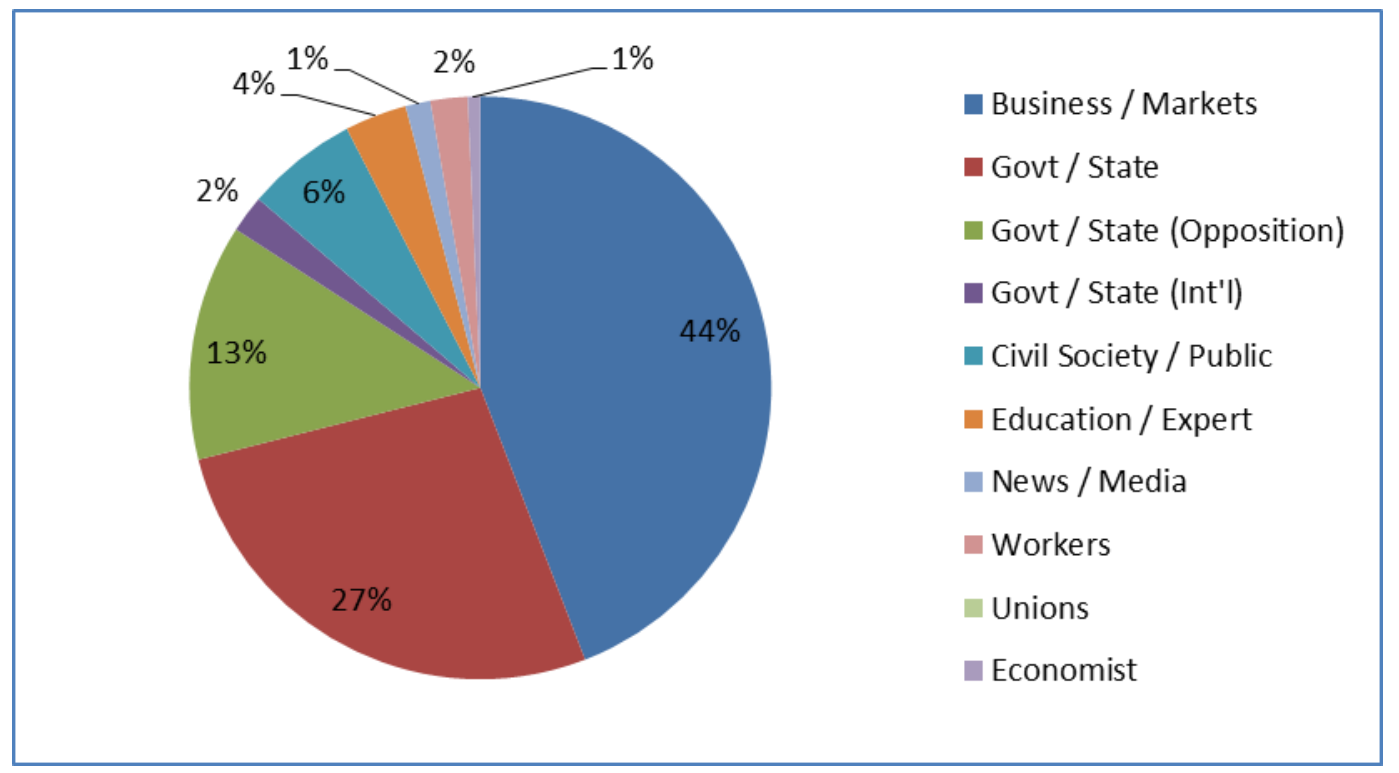

Figure 5: Total sources by percentage

\begin{tabular}{|l|c|c|c|c|}
\hline & Pro-Priv & $\begin{array}{l}\text { Not-Overtly- } \\
\text { Aligned }\end{array}$ & Anti-Priv & Total \\
\hline Business/Markets & 41 & 22 & 1 & 64 \\
\hline Govt/State & 18 & 19 & 2 & 39 \\
\hline $\begin{array}{l}\text { Govt/State } \\
\text { (Opposition) }\end{array}$ & 2 & 11 & 6 & 19 \\
\hline Govt/State (Int'I) & 0 & 3 & 0 & 3 \\
\hline Civil Society/Public & 3 & 3 & 3 & 9 \\
\hline Education/Expert & 0 & 4 & 0 & 2 \\
\hline News/Media & 2 & 0 & 0 & 3 \\
\hline Workers & 0 & 3 & 0 & 0 \\
\hline Unions & 0 & 0 & 13 & 145 \\
\hline Economists & 1 & 67 & & 1 \\
\hline Total & 67 & 65 & 0 & 5 \\
\hline
\end{tabular}

Figure 6: Sources coded by pro/anti/not-overtly-aligned towards privatisation 


\subsection{Framing Analysis}

Following analysis, three classifications of Frames emerged from the articles: Neoliberal, Critical and Miscellaneous. Neoliberal Frames were evidenced in all three categories of articles (Overtly Pro-Privatisation; Not-Overtly-Aligned; Overtly Anti-Privatisation). They were more numerous and more persistent than any other frames evidenced; and are consistent with the Neoliberal Frames identified in Preston and Silke's (2011) map of the key concepts of neoliberal discourse of the media. These include archetypal neoliberal constructs on deregulation and competition, market confidence, customer benefits, anti-state, anti-public service, anti-regulation, anti-worker, anti-union, critical of government and execution of privatisation procedures while supporting the policy itself. There were fewer Critical Frames, and these were evidenced only in articles categorised as Not-Overtly-Aligned and Overtly Anti-Privatisation (but not in the ones categorised as Overtly Pro-Privatisation). These critical frames comprise caution of new buyer, caution among workers of ownership change, scepticism of proposed savings, likely increase in household costs and, more prominently, under-valuation of state assets. Most striking of the Miscellaneous frame classification was the energy industry's role within regional economic imbalance; and the portrayal of 'hypocrisy' of the Sinn Féin Deputy Leader, Mary Lou McDonald TD. ${ }^{4}$

Of those articles that were classified as 'Not-Overtly-Aligned' in respect of their overt stance on the issue of the privatisation of BGÉ, quite a significant number were also classified as 'Anti-state' in their general framing of the issue.

While each of the articles was broadly classified into the three aforementioned categories (Pro-Privatisation, Not-Overtly-Aligned and Anti-Privatisation) an analysis of the frames within which these articles were presented provides us with a deeper understanding of their content and narratives. In order to be classified as 'Pro-Privatisation', an article had be adjudicated to be overtly or implicitly endorsing privatisation in its tone. However, upon examination, it became apparent that many of the articles classified as 'Not-Overtly-Aligned' did, in fact, contain many frames which mimicked those inherent to the 'Pro-Privatisation' articles, or what we might refer to as Neoliberal Frames. It could be argued that this is a more insidious form of ideological representation, being more subtly embedded within the text of the articles.

\subsection{Significant Silences}

It was noted by Money Guide Ireland in June 2014 that the Irish population was "probably not aware" that the privatisation had taken place and that even "[BGÉ's] own customers would not have noticed"; because, while the sale was approved by the European Union on 16 June, the takeover had "already quietly happened". Added to this is Rory Hearne's assertion that the Minister for Communications, Energy \& Natural Resources denied Bórd Gáis's privatisation on RTÉ, stating "We didn't privatise Bórd Gáis, we retained the networks in public ownership" (2015). As noted, Preston and Silke's conceptual framework of neoliberal discourse highlights the importance of significant silences, and stands in sharp contrast to the aforementioned media fanfare associated with the Eircom privatisation, and others such as Britain's first privatisation, British Telecom, in 1984 (Foreman-Peck 2004).

${ }^{4}$ The criticism of the Opposition Sinn Fein Deputy was for her disagreement (on ideological grounds) with the sale of BGÉ (given that her husband, Martin Lannigan, as an employee of BGÉ, stood to benefit from the sale as a member of the Employee Share Ownership Programme, which one newspaper - the Irish Daily Mail - depicted as "trousering up to $€ 60$-odd grand". 
It would seem likely that one of the most striking aspects of the review of the media output from 1 March to 1 August 2014, the period during which BGÉ was sold, is the lack of information in the news media both in the lead up to the sale and during its progression. As stated, the Trade Union input into the media 'debate' of the privatisation of BGÉ is conspicuous by its absence. This reflects a general lack of sources derived from workers and their representatives, which, arguably, is one of the most significant silences of all, confirming as it does a distinct lack of balance in the controversial privatisation debate.

Whether supportive of or against privatisation as a policy, one frame is especially noteworthy: of the relatively few articles categorised as anti-privatisation, this key frame was that the total BGE entity had been undervalued and therefore, sold at a loss to the state. Fewer than $4 \%$ of the total words published about BGÉ, in precisely five articles, published by the Irish media (during the period examined covering the sale) made any reference to this key point; two of those articles were written by a concerned member of the public and were featured in the Letters Section. This points to a serious deficiency on the part of the media in their treatment of the privatisation.

\section{Concluding Remarks}

In short, the media's coverage of the sale could not be found to be impartial: both the volume and thrust of the articles were inclined to portray privatisation in a favourable, non-critical light. The majority of content was presented within neoliberal frames. Few questions were asked, and the general nature of criticism took issue with the execution of the sale, rather than the policy itself. This is especially noteworthy since the Report of the Review Group on State Assets \& Liabilities' (2011) own Terms of Reference stipulates that the quest for privatisation was done as part of a debt management programme, yet the media's coverage of that sale was largely to champion it as a positive consumer development.

Findings are consistent with neoliberal, market-oriented frames generally. Specifically, this paper contends that the frames emerging here revolve around the idea of perceived benefits of market deregulation and competition; this was especially evident among the articles categorised as 'overtly pro-privatisation'. It is posited that market deregulation is a positive thing which will lead to competition which will in turn bring about the prospect of consumer switching and the potential for making savings. Other neoliberal frames among the pro-privatisation classification were an anti-state stance, specifically anti-public service, and drawing attention to perceived waste and excess in state-run organisations. This was supplemented with a typical anti-worker and particularly an anti-union position. Accompanying this classic market-oriented frame is the idea that the sale of the gas provider can be taken as a positive economic sign generally, following Ireland's well-documented economic difficulties post-crash.

What is especially interesting is that these frames were similarly evident among the articles that were analysed and classified as not-overtly aligned towards privatisation. So, what this demonstrates is that even those articles which seemed less partisan one way or another actually made the same assumptions as those that were overly ideological, thus demonstrating an insidious ideology or implicit subscription to market hegemony. Moreover, even the articles that were classified as overtly anti-privatisation still concurred with the same anti-government frames as the former categories. It was found that although there were problems associated with this particular sale of BGÉ, most notably its market timing, the policy of privatisation was not, in itself, in question. 
Examination of 'significant silences' within the media suggests to us that the issue of privatisation was not adequately teased out, either in terms of examining the appropriateness of the policy of privatisation in this instance, or the simple recognition of the manifestation of the sale itself. It was relatively difficult to ascertain whether, and when, the public utility had actually been sold; which points to a serious deficiency on the part of the media. Given the controversial nature of the topic both internationally and in Ireland, and the gravity of the Irish political and economic situation, many issues with regards to any proposed sale should have been tackled comprehensively.

Significant source bias was evident, manifesting in a particularly one-sided debate: one which viewed privatisation in a positive light. This predisposition placed additional onus upon journalists to apply rigorous critique to the neoliberal frames provided by the institutional elite sources they consulted, but unfortunately this was not carried out. This reinforces the nature of the power structure inherent in journalistic practices and has implications for the reporting of many similarly contested and class-based topics. Echoing Phelan's findings on the Eircom privatisation a decade earlier, this study found that any critique of privatisation that existed related to the handling and failures of the process, but did not question the ideological support for privatisation itself as a policy.

We can conclude from the evidence that much reportage was presented within neoliberal frames, reinforcing the theoretical findings of neoliberal assumptions and media bias. This is important, as although widespread media bias does not guarantee that the media audience will receive the ideological message inherent within the content unobstructed or uncontested (Hall 1980/2006), nonetheless, oppositional readings do not prevent the media setting the parameters (or framing) of the agenda in political, social and economic discourse (Cohen 1963). In this case the consumerist frame was paramount, and the extent of the discussion of the public good was the price for a single power station rather than a discussion about the privatisation itself. As discussed, this assumption of market superiority and narrow consumer interests, without debate, or recourse to the public good, is clearly neoliberal ideological construction.

Moreover, this paper argues that the very specialisation of business supplements and business journalism that is increasingly found in general news sections is in itself an ideological act; business journalism as opposed to broader economic journalism presupposes a narrowly-based readership of business actors such as managers and shareholders, as opposed to the general public, who at best are framed as consumers. If issues of public importance such as housing, healthcare, and energy supply are primarily reported in business pages, or in a narrow business context, this may assume a number of commercial frames such as success being measured in shareholder returns, rental yields or price indices' rather than broader societal frames such as the public good; this fits within the context of neoliberal ideological constructs.

Going forward, a more pluralistic approach to economic reporting, including heterodox economic voices, is something that a long-suffering public might expect from economic journalism.

\section{References}

Akram, Tanweer. 2003. Formulation of a Model of Ineffective Privatization in the Context of Developing Countries. Journal of Financial Management \& Analysis 16 (1): 27-35.

Allen, Kieran. 2009. Ireland's Economic Crash: A Radical Agenda for Change. 1st ed. Dublin: The Liffey Press.

Becker, Howard S. 1967. Whose Side Are You On? Social Problems 14(3): 239-247. 
Bel, Germà, Xavier Fageda, and Mildred E. Warner. 2010. Is Private Production of Public Services Cheaper than Public Production? A Meta-Regression Analysis of Solid Waste and Water Services. Journal of Policy Analysis and Management 29 (3): 553-577.

Boas, Taylor C., and Jordan Gans-Morse. 2009. Neoliberalism: From New Liberal Philosophy to Anti-Liberal Slogan. Studies in Comparative International Development 44 (2): 137161.

Bond, Patrick. 2003. The New Apartheid. New Internationalist 335. Accessed 16 October 2016. https://newint.org/features/2003/04/01/fightback-newapartheid/

Clarke, Thomas, ed. 1994. International Privatisation: Strategies and Practices. Berlin: Walter de Gruyter.

Cohen, Bernard, C. 1963. The Press and Foreign Policy. Princeton: Princeton University Press.

Davis, Aeron. 2002. Public Relations Democracy: Public Relations, Politics and the Mass Media in Britain. Manchester: Manchester University Press.

Davis, Aeron. 2007. The Mediation of Power: A Critical Introduction. London: Routledge.

de Beer, Arnold S., and Elanie Steyn. 2002. Sanef's '2002 South African National Journalism Skills Audit'. Ecquid Novi: African Journalism Studies 23 (1): 11-86.

Diokno-Pascual, Maitet. 2003. Fight Back! Power Splurge. New Internationalist 355. Accessed 3 November 2016. https://newint.org/features/2003/04/05/power/

Doğu, Burak. 2015. Comparing Online Alternative and Mainstream Media in Turkey: Coverage of the TEKEL Workers Protest against Privatization. International Journal of Communication 9: 630-651.

Duménil, Gérard, and Dominique Lévy. 2004. Capital Resurgent: Roots of the Neoliberal Revolution. Cambridge, MA: Harvard University Press.

Ellwood, Wayne. 2003. The Great Privatisation Grab. New Internationalist 355. Accessed 17 October 2016. https://newint.org/features/2003/04/01/keynote/

Ervia. 2015. Bórd Gáis Éireann Announces Definitive Agreement to sell Bórd Gáis Energy. Accessed 09 August 2017. http://www.tynaghenergy.ie/bord-gais-eireann-announces-definitive-agreement-to-sell-bord-gais-energy/

Fowler, Roger. 1991. Language in the News: Discourse and Ideology in the Press. London: Routledge.

Foreman-Peck, James. 2004. How Privatisation has Changed Britain. BBC News: Business. Accessed 09 August 2017. http://news.bbc.co.uk/1/hi/business/4061613.stm

Fraser, Matthew. 2009. Five Reasons for Crash Blindness. British Journalism Review 20 (78): 78-83.

Freedman, Des. 2008. The Politics of Media Policy. Cambridge: Polity Press.

Fürsich, Elfriede. 2009. In Defense of Textual Analysis: Restoring a Challenged Method for Journalism and Media Studies. Journalism studies 10 (2): 238-252.

George, Amanda. 2003. Fight Back: Crime Pays. New Internationalist 355. Accessed 09 August 2017. https://newint.org/features/2003/04/05/crime

Glaser, Barney G., and Anselm L. Strauss. 1967. The Discovery of Grounded Theory. New Brunswick: Transaction Publishers.

Halliday, Michael A. K. 1985. Introduction to Functional Grammar. London: Arnold.

Hall, David. 2003. The 'B' Word. New Internationalist 355. Accessed 16 October 2016. https://newint.org/features/2003/04/01/bureaucracy/

Hall, Stuart. 2006/1980. Encoding/Decoding. In Media and Cultural Studies: Keyworks, edited by Meenakshi Gigi Durhan and Douglas Kellner, 163-173. Malden: Blackwell.

Hall, Stuart, Chas Critcher, Tony Jefferson, John Clarke, and Brian Roberts. 1978. Policing the Crisis: Mugging, the State, and Law and Order. London: Macmillan.

Harvey, David. 2004. The 'New' Imperialism: Accumulation by Dispossession. Socialist Register 40: 63-87.

Haymes, Stephen, Maria Vidal de Haymes, and Reuben Miller, eds. 2015. The Routledge Handbook of Poverty in the United States. London: Routledge. 
Hearne, Rory. 2015. Why Privatising State Assets is not in the Public Interest. Irish Examiner, 26 January.

Herman, Edward S. 1982. The Institutionalization of Bias in Economics. Media, Culture \& Society 4: 275-291.

Irish Independent. 2013. INM Appoints Stephen Rae as Editor in Chief of Titles. 24 June. Accessed 3 November 2016. http://www.independent.ie/business/media/inm-appoints-stephen-rae-as-editor-in-chief-of-titles-29368529.html

Kariithi, Nixon, and Peter Kareithi. 2007. It's Off to Work You Go: A Critical Discourse Analysis of Media Coverage of the Anti-Privatisation Strike in South Africa in October 2002. Journalism Studies 8 (3): 465-480.

Letza, Steve R., Clive Smallman, and Xiuping Sun. 2004. Reframing Privatisation: Deconstructing the Myth of Efficiency. Policy Sciences 37 (2): 159-183.

Lundahl, Brad, Chelsea Kunz, Cyndi Brownell, Norma Harris, and M. S. W. Russ Van Vleet. 2007. Prison Privatization: A Meta-Analysis of Cost Effectiveness and Quality of Confinement Indicators. Utah Criminal Justice Center. Accessed 25 August 2017.

https://www.privateprisonnews.org/media/publications/utah criminal justice center college of social work private prison analysis 2007.pdf

Marx, Karl. 1967/1867. Capital, Volume I. New York: International Publishers.

Mayher, Anne, and David A. McDonald. 2007. The Print Media in South Africa: Paving the Way for Privatisation. Review of African Political Economy 34 (113): 443-460.

McCarthy, Colm. 2011. Review Group on State Assets and Liabilities. Dublin: Government of Ireland Press.

Meek, Colin. 1996. Privatisation Doesn't Necessarily Equal Competition: The UK Experience. In Who Benefits from Privatisation?, edited by Moazzem Hossain and Justin Malbon, 100119. London: Routledge.

Mercille, Julien and Enda Murphy. 2015. Conceptualising European Privatisation Processes After the Great Recession. Antipode 48 (3): 685-704.

Money Guide Ireland. 2014. Centrica Now Own Bórd Gáis Energy. Accessed 17 October 2016. http://www.moneyguideireland.com/centrica-now-own-bord-gais-energy.html

New Internationalist. 2003. Privatisation: The Facts. 1 April. Accessed 12 October 2016. https://newint.org/features/2003/04/01/facts/

Newstalk. 2014. EU Commission Approves Sale of Bórd Gáis Energy. 16 June. Accessed 25 January 2015. http://www.newstalk.com/reader/47.301.343/26820/0/

O'Donovan, Donal. 2014. State Will Net €950m from Bórd Gáis Sale. Irish Independent, 26 March. Accessed 12 October 2016. http://www.independent.ie/business/irish/state-willnet-950m-from-bord-gais-sale-30125066.html

Palcic, Dónal, and Eoin Reeves. 2011. Privatisation in Ireland: Lessons from a European Economy. Basingstoke: Palgrave Macmillan.

Palcic, Dónal, and Eoin Reeves. 2013. Privatising SOEs in Ireland: Is it Worth it? Privatisation and PPP Research Group, 1 February. Presented at the Irish Economy Conference, University of Limerick.

Palley, Thomas I. 2004. From Keynesianism to Neoliberalism: Shifting Paradigms in Economics. In Neoliberalism: A Critical Reader, edited by Alfredo Saad-Filho and Deborah Johnston, 20-29. London: Pluto Press.

Phelan, Sean. 2003. The Influence of Neoliberal Assumptions on Media Treatment of Political Economy in Ireland. PhD dissertation, Dublin City University.

Phelan, Sean. 2007. The Discursive Dynamics of Neoliberal Consensus: Irish Broadsheet Editorials and the Privatization of Eircom. Journal of Language and Politics 6 (1): 7-28.

Plehwe, Dieter. 2009. The Origins of the Neoliberal Economic Development Discourse. In The Road from Mont Pelerin, edited by Philip Mirowski and Dieter Plehwe, 238-279. Cambridge, MA: Harvard University Press.

Pollock, Allyson. 2003. Bad Medicine. New Internationalist 335, 1 April. Accessed 12 October 2016. https://newint.org/features/2003/04/01/healthcare/ 
Preston, Paschal. 2009. Making the News: Journalism and News Cultures in Contemporary Europe. New York: Routledge.

Preston, Paschal and Henry Silke. 2011. Market 'Realities': De-Coding Neoliberal Ideology and Media Discourses. Australian Journal of Communications 38 (3): 47-64.

Ram Mohan, T.T. 2002. Privatisation: Theory \& Evidence. Economic \& Political Weekly 36 (52): 4865-4871.

Reynolds, John. 2014. PAC may Probe the Sale of $€ 400 m$ Bórd Gáis Station. Irish Independent, 3 March. Accessed 16 October 2016. http://www.independent.ie/business/irish/pacmay-probe-the-sale-of-400m-bord-gais-station-30137705.html

Scheufele, Dietram A., and David Tewksbury. 2007. Framing, Agenda Setting and Priming: The Evolution of Three Media Effect Models. Journal of Communication 57 (1): 9-20.

Schiffrin, Anya, ed. 2011. Bad News: How America's Business Press Missed the Story of the Century. New York: New Press.

Sweeney, Paul. 2004. Selling Out? Privatisation in Ireland. Dublin: Tasc/New Island.

Tambini, Damian. 2010. What are Financial Journalists for? Journalism Studies 11 (2): 158174.

Thompson, Peter, A. 2003. Making the World Go Round? Communication, Information and Global Trajectories of Finance Capital. Southern Review 36 (3): 20-43.

Toye, John. 1993. Keynes, Russia and the State in Developing Countries. In Keynes and the Role of the State, edited by Alan Peacock, 239-265. London: Palgrave Macmillan.

Tuchman, Gaye. 1978. Making News: A Study in the Construction of Reality. New York: The Free Press.

Usher, Nikki. 2013. Ignored, Uninterested, and the Blame Game: How the New York Times, Marketplace, and The Street Distanced Themselves from Preventing the 2007-2009 Crisis. Journalism 14 (2): 190-207.

Van Horn, Rob and Philip Mirowski. 2009. The Rise of the Chicago School of Economics and the Birth of Neoliberalism. In The Road from Mont Pelerin, edited by Philip Mirowski and Dieter Plehwe, 139-158. Cambridge, MA: Harvard University Press.

Williamson, John. 2004. The Washington Consensus as Policy Prescription for Development. In the Practitioners of Development Lecture Series, delivered 13 January, World Bank. Washington, DC: Institute for International Economics.

Wodak, Ruth. 2007. What is CDA All About? In Methods of Critical Discourse Analysis, edited by Ruth Wodak and M. Meyer, 1-13. London: Sage.

\section{About the Authors}

\section{Ciara Graham}

Ciara Graham is a Lecturer in Business and Marketing at the Institute for Technology Tallaght in Dublin Ireland. Her research interests include the treatment of public enterprise in the media and the role of public enterprise in contemporary political economy.

\section{Henry Silke}

Henry Silke is a Lecturer in Journalism at the University of Limerick. His research interests include the role of journalism and communications in market systems and crisis. 